\title{
The Generation of Available Potential Energy by Sensible Heating along the East Coasts of Asia and North America
}

\author{
By Kyung D. Min* and Lyle H. Horn \\ Department of Meteorology, University of Wisconsin, Madison, Wisconsin 53706 \\ (Manuscript received 12 February 1973, in revised form 12 January 1974)
}

\begin{abstract}
The generation of available potential energy by sensible heating is studied for the cyclogenetic regions along the east coasts of Asia and North America for a data period of four Decembers and four Januarys. Radiosonde data are used to prepare daily cross sections oriented perpendicular to the Asian and North American coasts. From the cross sections daily values of the efficiency factors are calculated. The bulk aerodynamic method is used to estimate the daily sensible heat flux over the ocean near Shionomisaki, Japan and Cape Hatteras, U.S.A. Using the efficiency factors and sensible heat flux, total mean generation estimates of 3.85 watts $/ \mathrm{m}^{2}$ near Shionomisaki and 1.66 watts $/ \mathrm{m}^{2}$ near Cape Hatteras are obtained. The larger value for Asia is due to the larger efficiency factor values found along the east coast of Asia. Estimates of the frictional dissipation of kinetic energy in the two areas are also made. Near Cape Hatteras the mean generation by sensible heating exceeds the frictional dissipation, while near Shionomisaki the frictional dissipation somewhat exceeds the generation.
\end{abstract}

\section{Introduction}

The east coasts of Asia and North America are two of the most favored regions for cyclogenesis in the Northern Hemisphere. The cyclogenesis is often so rapid that it may transform an apparently innocuous weather situation into a major storm within twelve to twenty-four hours. Figs. 1 and 2 show the principal areas of cyclogenesis in these coastal areas during winter (U.S. Navy Marine Climatic Atlas, 1957). In winter these regions are characterized by a large temperature contrast between the cold continents and warmer oceans, especially where the Kuroshio Current and the Gulf Stream parallel the coasts. During periods of strong outbreaks of cold continental air, the sensible heat transfer at the air-sea interface reaches very large values. Winston (1955), Reed (1958) and Petterssen et al. (1962) have found that sensible heating is a significant factor for the development of cyclones. Manabe (1958), Pyke (1965), Laevastu (1965) and others have shown that there is maximum transfer of

* Present affiliation: Department of Earth Science Kyungpook National University, Taegu, Korea sensible heat from the ocean to the atmosphere and latent heat release during and just before rapid cyclogenesis. Although the exact mechanism of cyclogenesis remains uncertain, the concept of available potential energy as presented by Lorenz (1955a) and Dutton and Johnson (1967) has provided additional insight into the problem.

The work of Lorenz (1955a), involving the available potential energy of the atmosphere, resulted in a great deal of attention being focussed on the energetics of cyclones. A number of investigators have used the approximate form of Lorenz's equations in various empirical studies of the energy cycle. See Oort (1964) for a summary of the results. An apparent paradox in using Lorenz's equations in their approximate form is that in the regions of frequent and intense cyclogenesis off the east coasts of Asia and North America, the strong sensible heating of cold air as it moves out over the warm ocean is a process which destroys eddy available potential energy. This is in contradiction to the view that sensible heating is important in producing cyclogenesis in these regions.

Dutton and Johnson (1967) have pointed out that the paradox can be resolved by retaining the 


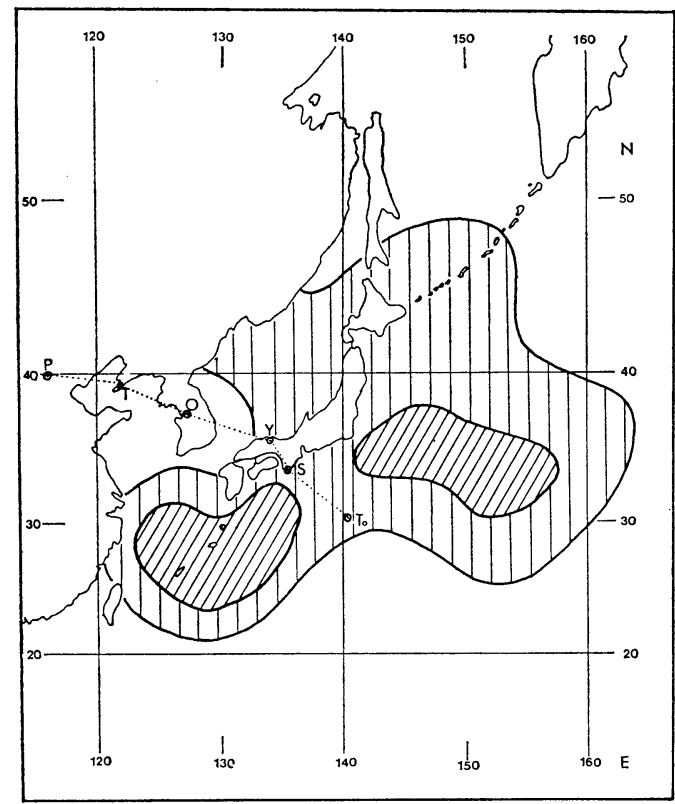

Fig. 1. The principal area of cyclogenesis off the coast of Asia during winter. Vertical stripes indicate the area of cyclogenesis within which there is a smaller area (diagonal stripes) where cyclogenesis is concentrated. From U.S. Navy Marine Climatic Atlas (1957). Dotted line represents the cross section used in this study.

available potential energy equations in their exact form. Lorenz (1955b), in a less well known work than his 1955a paper, obtained expressions similar to those obtained by Dutton and Johnson (1967), however, before 1967 all the empirical studies were based on the approximate equations. The exact form of the equations shows that heat addition at high pressure on an isentropic surface creates rather than destroys available potential energy. This is consistent with observations of cyclogenesis over the oceans just east of Asia and North America. Recently, several investigators have used the exact form of the equations to examine the importance of latent and sensible heating in the generation of available potential energy in individual cyclones. For example, see Bullock and Johnson (1971a, 1971b) and Gall and Johnson (1971). However, there have been no investigations of the climatology of the generation of available potential energy in the regions of frequent cyclogenesis along the east coasts of Asia and North America. In this paper a climatological

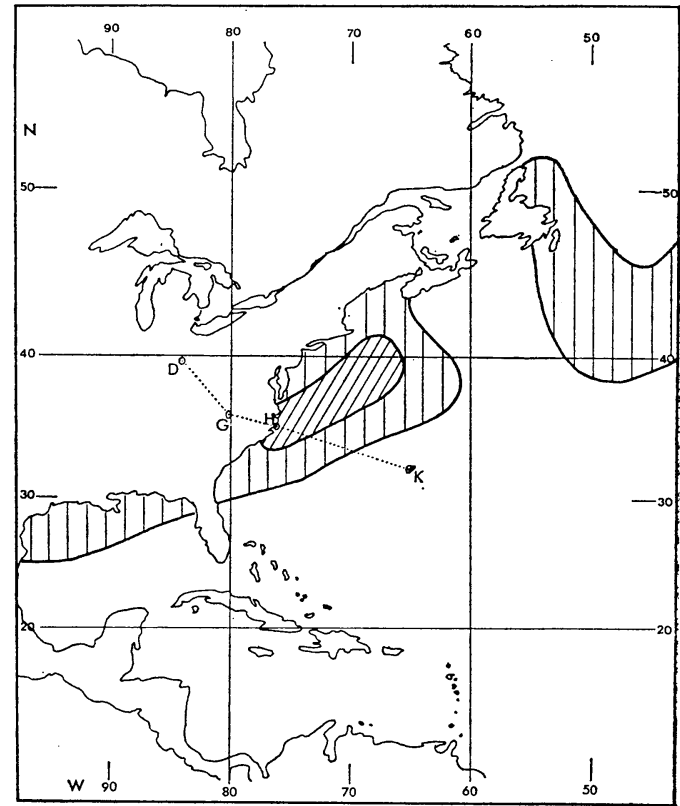

Fig. 2. The principal area of cyclogenesis off the coast of North America during winter. See Fig. 1 for other explanation. From U.S. Navy Marine Climatic Atlas (1955).

approach is used to study the generation of available potential energy by sensible heating in these east coast areas. The procedure used is set forth in the following section.

\section{The basic equations and general procedure}

According to Johnson (1970), the time rate of change of available potential energy for any volume is

$$
\frac{d A}{d t}=G(A)-C(A, K)+B(A)+W(A)
$$

where $A$ is available potential energy, $t$ is the time, $G(A)$ is the generation of available potential energy, $C(A, K)$ is the conversion of available potential energy to kinetic energy within the volume, $B(A)$ is the advection through the boundary, and $W(A)$ is the pressure work done on the boundary.

The kinetic energy budget equation for a volume is

$$
\frac{d K}{d t}=C(A, K)+B(K)-D(K)
$$

where $K$ is kinetic energy, $B(K)$ is the advection 
of kinetic energy into or out of the volume and $D(K)$ is the frictional dissipation of kinetic energy. The conversion term, $C(A, K)$, which appears in both equation (1) and (2) but with opposite sign, represents the production of kinetic energy at the expense of available potential energy.

While most empirical studies of the atmosphere's energy processes have attempted to obtain estimates for the whole domain of the atmosphere, the above equations can be used to describe the energy processes within a limited volume of the atmosphere; e.g., as noted by Johnson (1970) a volume may be chosen which includes only a single storm. Although the equations permit a diagnosis of the energy processes within a limited volume, they cannot describe the type of circulation that will occur since an energetics approach alone cannot describe the dynamics of the circulation. This, of course, applies whether the domain is the whole atmosphere or only a limited volume.

In this study, our interest is in the generation term of equation (1). In particular we wish to examine the contribution of sensible heating to the generation of available potential energy. In pressure coordinates the generation is

$$
G(A)=\frac{1}{g} \int_{\sigma} \int_{p}\left[1-\left(\frac{p_{r}}{p}\right)^{\kappa}\right] Q_{m} d p d \sigma
$$

where $g$ is gravitational acceleration, $p$ is pressure, $p_{r}$ (called the reference pressure) is the areal average of the pressure on an isentropic surface, $\kappa$ is the ratio of the specific gas constant to the specific heat at constant pressure, $Q_{m}$ is the rate of diabatic heating per unit mass and $\sigma$ is area. The diabatic heating $\left(Q_{m}\right)$ represents the sum of all diabatic processes, however, in this study only the contribution of sensible heating is estimated.

The quantity,

$$
\varepsilon=\left[1-\left(\frac{p_{r}}{p}\right)^{\kappa}\right]
$$

usually referred to as the efficiency factor, represents the effectiveness of heating at any point in producing available potential energy. In regions where $p>p_{r}$, heat addition generates available potential energy. On the other hand, in region where $p>p_{r}$ cooling generates available potential energy.

According to the bulk aerodynamic method the sensible heat flux is given by

$$
Q_{s}=\rho c_{p} C_{d}(z)\left[T_{s}(0)-T_{a}(z)\right] U_{a}(z)
$$

where the subscripts 0 and $z$ refer to the two observing levels and $s$ and $a$ refer to the sea and air. $C_{d}$ and $U_{a}$ are the drag coefficient and wind speed at height $z$. This method has been widely used in many recent studies (Malkus 1962, Petterssen et al., 1962, Pyke 1965, Gall and Johnson 1971, Ninomiya 1972).

Assuming horizontal homogeneity and applying the hydrostatic approximation, the sensible heat addition per unit mass is

$$
Q_{m}=g \frac{\partial Q_{s}}{\partial p}
$$

Thus the sensible heating is determined by the vertical divergence of the flux. The depth of layer through which the sensible heating occurs is dependent on the static stability of the atmosphere which in turn is partly determined by the amount of sensible heat transfer.

In this study the basic equations discussed above are used to describe the generation of available potential energy by sensible heating in the volumes of the atmosphere which occupy the eastern coastal regions of Asia and North America. Rather than evaluating the sensible heating over an entire volume, we have chosen to construct daily isentropic cross sections which cut through the volume and are oriented perpendicular to the coastline. From the isentropic data efficiency factors are calculated for the cross sections. At two selected coastal stations daily estimates of the sensible heating are made and combined with the efficiency factors to estimate the generation of available potential energy in the lower troposphere where sensible heating is significant. These daily estimates, which are made for a data period of eight months, are averaged to obtain climatological estimates of the generation. The climatological estimates are considered reasonably representative of the generation by sensible heating in these east coastal areas.

\section{Data and computational methods}

Basic Data. The principal data source for this study is the Northern Hemispheric Data Tabulation (U.S. Weather Bureau) for the months of December and January for the years 1957-1962, except for December and January 1959 which were 
Table 1. Geographical elements of the data stations. The North American values in ( ) are for the modified cross section described in the text.

\begin{tabular}{l|l|r|r|c|c|c}
\hline & Station & Lat. & Long. & Elev. & $\begin{array}{l}\text { Symbol on } \\
\text { cross section }\end{array}$ & $d_{i}$ \\
\hline \multirow{5}{*}{ Asia } & Peking & N $39^{\circ} 55^{\prime}$ & E $116^{\circ} 25^{\prime}$ & $64 \mathrm{~m}$ & $\mathbf{P}$ & 4.6 \\
& Talien & 3854 & 12138 & 95 & $\mathrm{~T}$ & 4.9 \\
& Osan & 3706 & 12702 & 12 & $\mathrm{O}$ & 5.7 \\
& Yonago & 3526 & 13321 & 8 & $\mathrm{Y}$ & 4.7 \\
& Shionomisaki & 3327 & 13546 & 73 & $\mathrm{~S}$ & 4.3 \\
& Torishima & 3029 & 14018 & 83 & To & 5.4 \\
\hline \multirow{3}{*}{ North } & Dayton & N $39^{\circ} 54^{\prime}$ & W $84^{\circ} 13^{\prime}$ & $306 \mathrm{~m}$ & D & $5.6(5.6)$ \\
& Greensboro & 3605 & 7957 & 275 & G & $4.7(4.7)$ \\
& Cape Hatteras & 3516 & 7533 & 3 & H & $7.2(3.3)$ \\
& Kindley, Bermuda & 3222 & 6441 & 6 & K(or H-K) & $10.5(2.7)$ \\
\hline
\end{tabular}

not available. Data were also missing for certain individual days. The $00 \mathrm{Z}$ radiosonde observations in Asia and $12 \mathrm{Z}$ in North America were used so that the observations would be at nearly comparable sun times.

Since the daily sea surface temperature were not available, the mean sea surface temperature for December and January were obtained from the U.S. Navy Marine Clmatic Atlas of the World (1969). Because the sea surface temperatures near the coast line change only slightly from day to day, the use of monthly mean values appears justified. In computing sensible heat flux it is the variations in air temperature and wind speed that account for nearly all the daily variations in heating, and for these parameters daily values were available.

The six Asian stations and four American stations listed in Table 1 were chosen for the study because they form reasonably straight lines, which pass through the areas of frequent cyclogenesis. Also see Figures 1 and 2 for station locations.

Computation of the efficiency factor. To obtain the reference pressure used in calculating efficiency factors the following expression was used,

$$
p_{r}\left(\theta_{j}\right)=\frac{\sum_{i=1}^{n} p_{i}\left(\theta_{j}\right) d_{i}}{\sum d_{i}}
$$

where $\theta_{j}$ is the $j$ th isentropic surface and $d_{i}$ is a weighting function for the $i$ th station. The reference pressures were calculated for $5^{\circ} \mathrm{K}$ intervals of $\theta$. The weight $d_{i}$ for a station was based on the distance between it and the midpoint to each of the two adjacent stations. Then using equation (4) the efficiency factors were computed for each day, and through interpolation values were obtained at $50 \mathrm{mb}$ intervals from the 1000 to 100 mbs. Mean December asd January efficiency factors were calculated from the daily values for both the Asian and North American cross sections.

Computation of sensible heat flux. Equation (5) was used to estimate the sensible heat flux over the ocean waters adjacent to Shionomisaki and Cape Hatteras. It was assumed that the heat flux at these two locations is a reasonable estimate of the sensible heating in a zone extending seaward from the coastline for approximately $100 \mathrm{~km}$.

To estimate the drag coefficient needed in equation (5) the following equation for nearneutral conditions proposed by Deacon and Webb (1962) for flow over water was used,

$$
C_{10}=\left(1.00+0.07 u_{10}\right) \times 10^{-3}
$$

where $C_{10}$ and $u_{10}$ are the drag coefficient and wind speed at the 10 meter height, respectively. Because the daily variations in drag coefficient are very small compared to the other parameters used in obtaining the sensible heat flux, the mean wind speeds near Shionomisaki and at Cape Hatteras during the data period were used to evaluate the drag coefficients.

Since the wind observations were not taken directly over the ocean, the exposure of the anemometers at these stations is of considerable importance. At Cape Hatteras the anemometer height of 9.7 meters above a nearly flat surface 
close to the water's edge gives an ideal exposure. However, at Shionomisaki the anemometer is 87.5 meters above the sea on a cape with the distance to the water's edge varying from 0.5 to $2.0 \mathrm{~km}$ depending on direction. Fortunately, during 1968-70 the Marine Meteorological Observatory of the Japan Meteorological Agency made a comparison of the wind conditions recorded by the station's anemometer with those made by an observation ship in the adjacent sea. The results of the study have been kindly made available by the senior meteorologist of the Shionomisaki station (personal communication, 1972). The following regression equation from the study has been used to estimate the 10 meter wind speed over the nearby water:

$$
U_{s}=1.61 U_{s n}
$$

where $U_{s}$ is the wind at about 10 meters above the sea and $U_{s n}$ is the wind speed recorded by the Shionomisaki anemometer. The larger values at 10 meters over the sea are due to the open exposure of the sea.

Using the mean wind speed of $5.5 \mathrm{~m} / \mathrm{sec}$ at Cape Hatteras and the adjusted value $\left(U_{s}\right)$ of $9.2 \mathrm{~m} / \mathrm{sec}$ near Shionomisaki, drag coefficients of $1.38 \times 10^{-3}$ and $1.64 \times 10^{-3}$, respectively, were obtained. The resulting constant $\left(\rho c_{p} C_{d}\right)$ is 4.24 $\times 10^{-5}$ for the North American east coast and $5.04 \times 10^{-5}$ for the Asian east coast.

Since daily sea surface temperatures were not available in the area of interest, the mean monthly December and January sea surface temperatures at a distance $80 \mathrm{~km}$ from the coast were estimated from the Marine Climatic Atlas of the World (U.S. Naval Weather Service Command, 1969). The value of sea surface temperatures are listed in Table 2.

Table 2. Values of sea surface temperature used in this study.

\begin{tabular}{l|c|c} 
& December & January \\
\hline Asia & $18.2^{\circ} \mathrm{C}$ & $15.7^{\circ} \mathrm{C}$ \\
North America & $19.3^{\circ} \mathrm{C}$ & $15.6^{\circ} \mathrm{C}$ \\
\hline
\end{tabular}

The daily surface air temperatures at Shionomisaki (00Z) and Cape Hatteras (12Z) were used to estimate the air temperatures at 10 meters above the sea. At Shionomisaki $0.7^{\circ} \mathrm{C}$ was arbitrarily added to the recorded temperature to take into account the fact the shelter is approximately 70 meters higher than at Cape Hatteras. When there is cold advection over these regions it is reasonable to assume that the lapse rate in the first $70-80$ meters is nearly dry adiabatic.

In estimating the generation of available potential energy by sensible heating it is necessary to specify the depth of the atmosphere to which the sensible heat is added. Because of its tremendous heat capacity, the sea can be considered as a continuous heat source whenever the air temperature is lower than the sea surface temperature.

The heat enters the atmosphere at the air-sea interface and is transferred upward through eddy conduction. In regions such as along the east coasts of Asia and North America the winter-time continental polar air is much colder than the oceans, and as a result when the air moves over the sea the vertical transfer of heat is vigorous. In the lowest few millibars the lapse rate will be superadiabatic with a rather deep adiabatic layer above. For the purpose of this climatological investigation the top of the adiabatic layer has been chosen at $900 \mathrm{mb}$. However, (in estimating the generation two vertical distributions of heating have been used. In what is perhaps the most realistic distribution, the heating is distributed through the entire adiabatic layer (approximately $1000-900 \mathrm{mb}$ ). In the other case the heat is added only at the $1000 \mathrm{mb}$ level which is very near the interface.

In estimating the sensible heating days on which the air temperature was warmer than the sea were treated as if the sensible heating were zero. Actually the transfer would be slightly negative, however, the strong thermal stratification, which exists when there is warm advection over colder water, so severely inhibits the vertical exchange that it is reasonable to set the heating at zero. It should be noted that during the entire data period there were only 4 days (out of a total 185) along the Asian coast and 3 days (out of a total of 233) along the North American coast when the air temperature was warmer than the sea temperature.

Computation of the generation term. By combining Equations (3) and (6), the working form of the generation equation used in this study becomes 


$$
G=\varepsilon(p) Q_{s}
$$

Using (10) two estimates of the generation were made. In one case the product of the sensible heating $\left(Q_{s}\right)$ and efficiency factor at $1000 \mathrm{mb}$ was calculated to estimate the generation, and in the other, more realistic case, the heating was assumed to be distributed through the $1000-900 \mathrm{mb}$ layer. In this case the sensible heating value was multiplied by the linear mean value of the efficiency factors at 1000,950 and $900 \mathrm{mb}$. Since the efficiency factor usually decreases with height, the second case gives a somewhat lower generation estimate. The first case may be thought of as a maximum possible generation for a given situation.

The generation estimates were partitioned into mean and time deviation parts by letting $\varepsilon=\bar{\varepsilon}+\varepsilon^{\prime}$ and $Q_{s}=\bar{Q}_{s}+Q_{s}{ }^{\prime}$ where (-) is the time mean and ()$^{\prime}$ is the deviation from the mean. Thus the total mean generation is

$$
G=\bar{\varepsilon} \overline{Q_{s}}+\overline{\varepsilon^{\prime} Q_{s}{ }^{\prime}}
$$

The first term on the right-hand side of (11) represents the steady or time averaged contribution to the total mean, while the second term represents the non-steady or time varying contribution to the generation.

Computation of the dissipation of kinetic energy. To compare the size of the mean generation with the mean frictional dissipation of kinetic energy at the coastal stations, Lettau's (1962) formulation for frictional dissipation was used,

$$
D(k)=\rho C_{g}{ }^{2} u_{g}{ }^{3} \cos \alpha
$$

where $C_{g}$ is the geostrophic drag coefficient, $u_{g}$ is the surface geostrophic wind speed and $\alpha$ is the angular departure of the geostrophic wind vector from the surface stress. Although the angular departure varies with the roughness of the surface, a constant value of 20 degrees was used in this study.

To obtain the geostrophic drag coefficient, Kung's (1963) regression equation was used,

$$
C_{g}=k /\left[\ln \left(\frac{u_{g}}{f z_{0}}\right)-1.865\right]
$$

where $f$ is the coriolis parameter, $k$ the Karman constant and $z_{0}$ the roughness height. The equation has two unknown parameters, $u_{g}$ and $z_{0}$. The value of $u_{g}$ was estimated using Lettau's (1962) formula

$$
u_{g}=\frac{u_{10} \cdot k}{C_{g} \ln \left(\frac{z_{10}+z_{0}}{z_{0}}\right)}
$$

where $z_{10}$ is the 10 meter height. The roughness parameter $z_{0}$, common to both equations (13) and (14), was estimated using the following equation from Roll (1965):

$$
z_{0} \cong z_{10} \exp \left(-k / \sqrt{C_{10}}\right) .
$$

Equations (13-15) and an iterative method were used to calculate $C_{g}$ and $u_{g}$. As a first guess $u_{g}$ was taken as twice the mean wind speed and $C_{10}$ was estimated from Equation (8). The revised values of $C_{g}$ and $u_{g}$ were then used for the next iteration. Three or four such iterations were sufficient to get a stabilized values of $C_{g}$ and $u_{g}$. Thus daily estimates of the frictional dissipation were obtained for the Shionomisaki and Cape Hatteras areas.

\section{Results}

The procedures described in the previous section were used to estimate the efficiency factors, sensible heat flux, generation of available potential energy and frictional dissipation of kinetic energy. The use of December and January data from the Asian and North American stations make it possible to study the role of sensible heating in the generation of available potential energy during the time of year when there is frequent cyclogenesis in these areas.

Mean efficiency factor field. The efficiency factor, which determines the effectiveness of heating or cooling in producing available potential energy, is dependent on the distribution of pressure on an isentropic surface. In the east coastal regions of Asia and North America the pressure near the ocean surface will generally be higher than the mean pressure for the isentropic surface since the isentropic surfaces slope quite steeply upward over the cold continents. Thus the strong baroclinity, which exists in these east coastal areas, favors a distribution of efficiency factors which is conducive to the generation of available potential energy by sensible heating whenever cold air moves over the warmer oceans. 


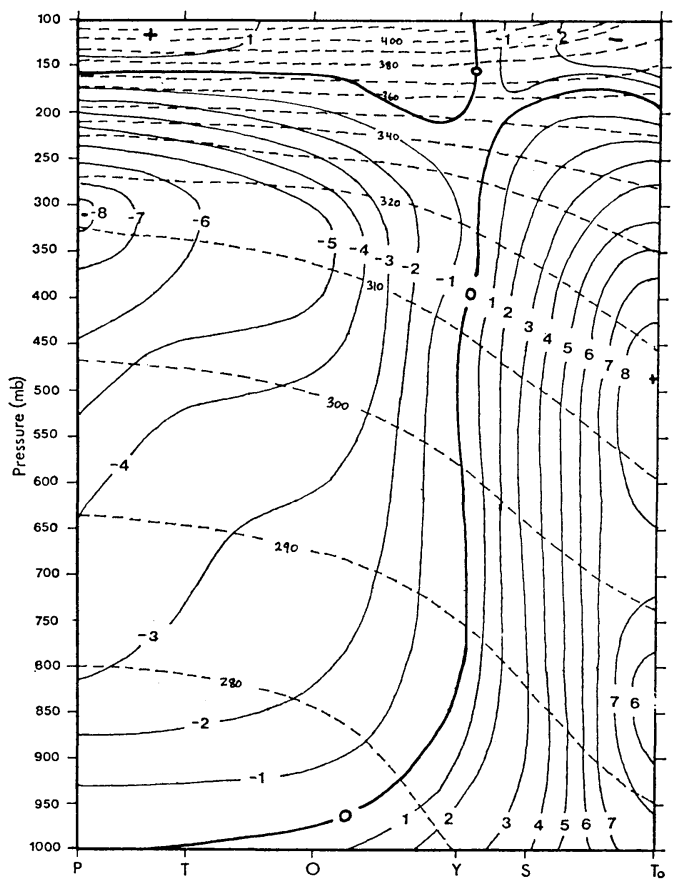

Fig. 3. Cross section of mean efficiency factors $\left(\times 10^{-2}\right)$ for Asian sector for December. Dashed lines are isentropes $\left({ }^{\circ} \mathrm{K}\right)$.

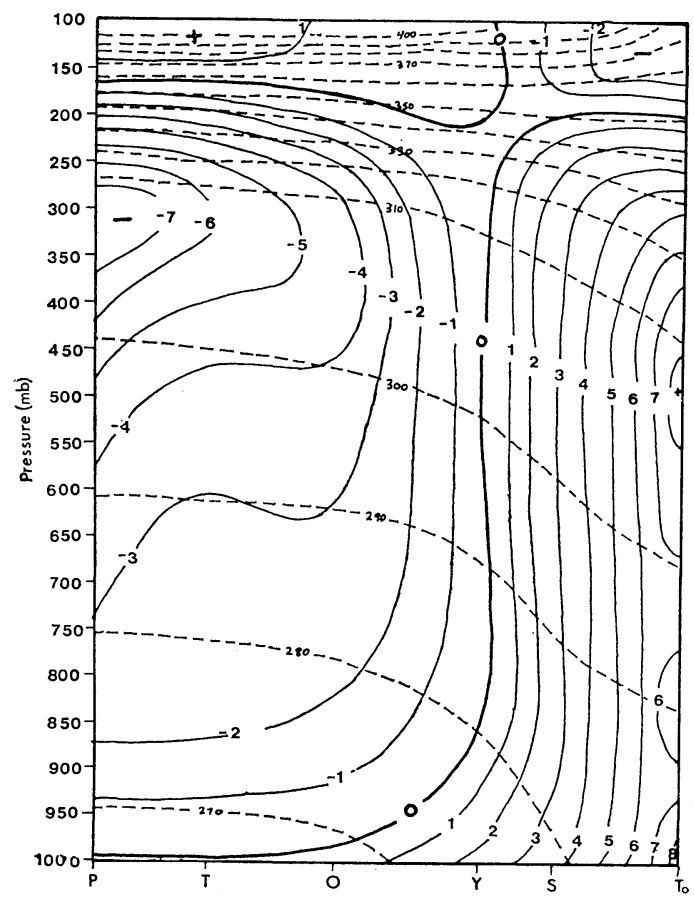

Fig. 4. Same as Fig. 3, except for January.



Fig. 5. Cross section of mean efficiency factors $\left(\times 10^{-2}\right)$ for North American sector for December. Dashed lines are isentropes $\left({ }^{\circ} \mathrm{K}\right)$.

Figs. 3 to 6 depict the mean December and mean January isentropes and efficiency factors. along the Asian and North American cross sections. Of particular importance is the zero efficiency factor lines. For both the Asian and North American cross sections, the line has a somewhat " $S$ " shape with positive values found near the surface along most of the cross section and to a great height in the warmer portion of the cross section. Similar patterns have been obtained by Dutton and Johnson (1967) and Lorenz (1967) but for much larger scales, and by Hahn and Horn (1969) and Gall and Johnson (1971) for individual cyclones.

For both Asia and North America there is little change in the cross sections of efficiency factors between December and January. However, there is an appreciable difference between the Asian and North American cross sections. Although both have the same general pattern, the absolute magnitude of the Asian efficiency factors 


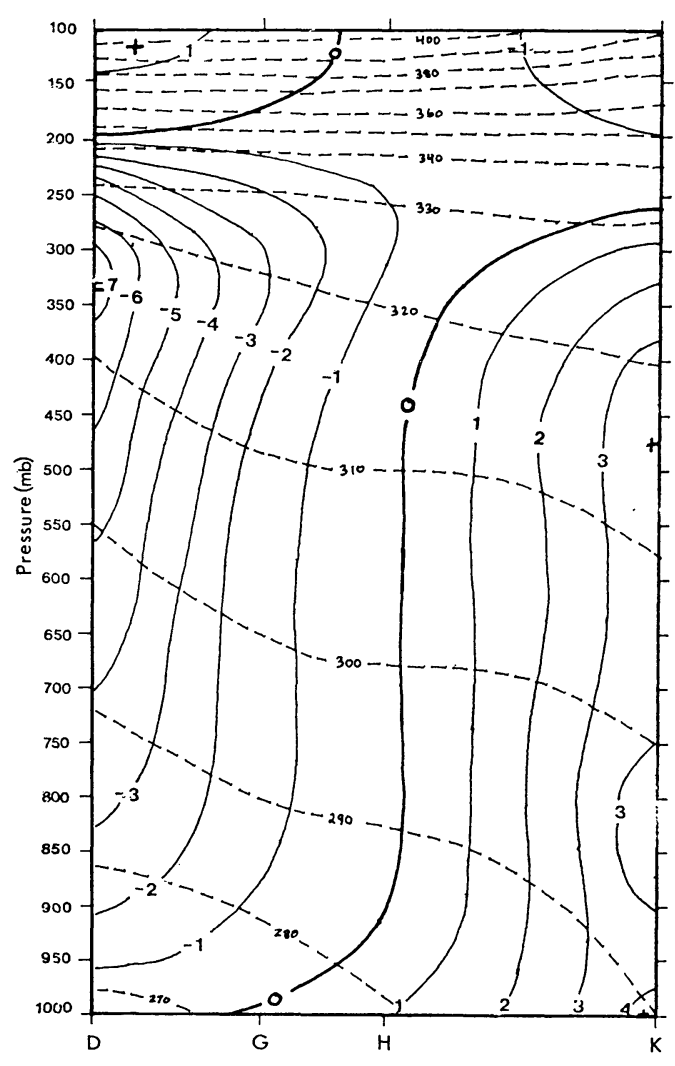

Fig. 6. Same as Fig. 5, except for January.

is larger. For example, in December the values of the Asian efficiency factors range from about $+80 \times 10^{-3}$ to $-80 \times 10^{-3}$, while in North America the range is from about $+35 \times 10^{-3}$ to $-70 \times 10^{-3}$. Thus for comparable patterns and magnitudes of heating and cooling the generation of available potential energy in the Asian region will be larger than in North America. Thus the large thermal contrast between the Asian mainland and warm Pacific Ocean not only results in the maximum Northern Hemisphere mean wind speeds being found above Japan, but also makes possible the very efficient use of diabatic heating in generating available potential energy.

Although this study is concerned with the generation of available potential energy by sensible heating, the efficiency factor distributions reveal that other diabatic processes, particularly latent heating, can be very effective in generating available potential energy in these regions. The release of latent heat in the region of large positive factors between about $900 \mathrm{mb}$ and $500 \mathrm{mb}$ over the ocean can be especially efficient. The absorp- tion of solar radiation in the warm moist air in this region can also contribute to the generation. Infrared cooling in the regions of large negative efficiency factor in the upper troposphere over the continents may also contribute to the generation if it is not compensated for by strong infrared cooling in the region below 300 or $400 \mathrm{mb}$ over the oceans.

As noted previously estimates of the sensible heating were calculated for the ocean areas near Shionomisaki and Cape Hatteras. An examination of the efficiency factor cross sections reveals that, while the efficiency factors in the lower atmosphere near Shionomisaki are definitely positive, those near Cape Hatteras are only slightly positive; i.e., the zero efficiency factor line is near Cape Hatteras. Because of the large distance between Cape Hatteras and Kindley (Bermuda), the position of Cape Hatteras in near the midpoint of the North American cross section where the efficiency factors are normally near zero. To reduce the heavy weighting given to the Kindley data, a modified cross section was prepared for the North American area. In order to obtain a cross section in which Cape Hatteras is located in a position comparable to that of Shionomisaki in the Asian cross section, a fictitious station was established between Cape Hatteras and Kindley to replace Kindley. The fictitious station, which we shall denote as $\mathrm{H}-\mathrm{K}$, was positioned $267 \mathrm{~km}$ east of Cape Hatteras. This distance represents 0.22 the total distance of the modified North American cross section. On the Asian cross section the distance between Torishima and Shionomisaki represents 0.22 of the total distance of the Asian cross section. By using the modified North American cross section Cape Hatteras and Shionomisaki share comparable relative positions and thus the generation estimates obtained for the two stations can be more realistically compared. The basic data for station H-K was obtained by interpolating between the daily data values at Cape Hatteras and Kindley. Since Kindley is located approximatley $1052 \mathrm{~km}$ from Cape Hatteras, an interpolation factor of $267 / 1052$ was employed.

The modified cross sections for the North American area are presented in Figs. 7 and 8. In these the efficiency factors in the lower atmosphere near Cape Hatteras are about $20 \times 10^{-3}$ compared with about $35 \times 10^{-3}$ from the cross sections for the Shionomisaki area. The larger 




Fig. 7. Modified cross section of mean efficiency factors $\left(\times 10^{-2}\right)$ for North American sector for December. Dashed lines are isentropes $\left({ }^{\circ} \mathrm{K}\right)$. See text for discussion of the modifications made.

Table 3. Mean sensible heat flux $\left(\times 10^{-3} \mathrm{cal} / \mathrm{cm}^{2}\right.$ sec) along the east coasts of Asia and North America.

\begin{tabular}{l|c|c}
\hline & (Shionomisaki) & $\frac{\text { Asia }}{\text { (Cape Hatteras) }}$ \\
\hline $\begin{array}{c}\text { December } \\
(1957,58,60,61)\end{array}$ & 2.05 & 2.63 \\
$\begin{array}{c}\text { January } \\
(1958,60,61,62)\end{array}$ & 4.09 & 3.06 \\
\hline
\end{tabular}

values at Shionomisaki mainly reflect the greater variation of pressure on an isentropic surface (i.e., greater baroclinity) in the Asian sector.

Mean Sensible Heat Flux. Equation (5) was used to obtain daily estimates of the sensible heat flux near Shionomisaki and Cape Hatteras. The mean values are presented in Table 3. The December mean value for the Asian station was somewhat smaller than the mean for North America, while the January mean for Asia was 1.3 times larger than for North America. From

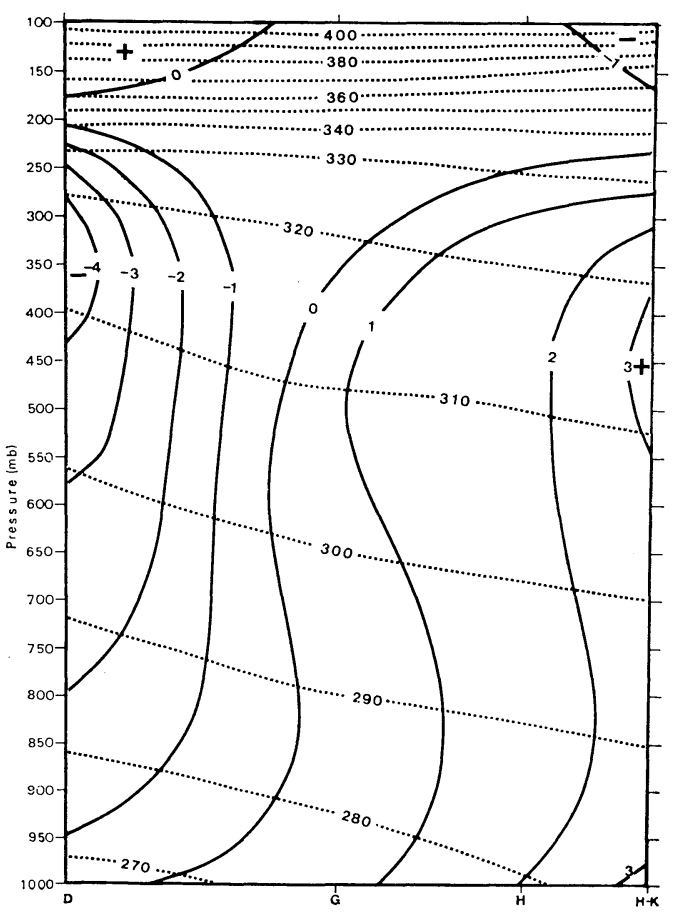

Fig. 8. Same as Fig. 7, except for January.

Table 4. Values of sensible heat flux $\left(\times 10^{-3} \mathrm{cal} / \mathrm{cm}^{2}\right.$ sec) obtained by several investigators for east coastal regions.

\begin{tabular}{ll|lr}
\hline \multicolumn{1}{c|}{ Asia } & & \multicolumn{2}{|c}{ North America } \\
\hline Manabe (1958) & 7.0 & Petterssen et al., (1962) & 8.0 \\
Ninomiya (1972) & 3.1 & Gall \& Johnson (1971) & 3.5, \\
Min \& Horn & 3.1 & Min \& Horn & 2.8 \\
\hline
\end{tabular}

December to January there was a small increase in sensible heat flux in the North American area, but a doubling in the Asian sector. Since the mean wind speed near Shionomisaki for December was $8.9 \mathrm{~m} / \mathrm{sec}$ and for January was $9.6 \mathrm{~m} / \mathrm{sec}$, the principal cause of the increase in sensible heating between December and January must have been an increase in air-sea temperature differences. This would indicate more frequent cold outbreaks in the Asian sector in January, since the mean sea surface temperature decreased by nearly $3^{\circ} \mathrm{C}$ between December and January.

A few estimates of mean sensible heat flux along the east coastal regions made in other studies are available for comparison and are presented in Table 4. Manabe's (1958) estimate, which was for the Sea of Japan during January and February, 
1955, is twice that obtained for the combined December-January data period of this study. It should be noted that the Sea of Japan is closer to the Asian mainland so that continental air reaching the Pacific coast of Japan is modified in passing over the Sea of Japan. Ninomiya's (1972) estimate, based on an areal average sensible heat flux over the East China Sea for February 1966, 1967 , and 1968, is the same as the mean of the December and January values obtained in this study.

For the North Atlantic Ocean the estimate of Petterssen et al., (1962) is for typical case of cyclone development in the Atlantic east of Cape Hatteras. Since their composite value was based only on days on which cyclogenesis occurred, the relatively large value seems reasonable. Gall and Johnson (1971) estimated the sensible heat flux associated with an intense cyclone over the North Atlantic Ocean. For a constant $z_{0}$ (as was also used in this study) they obtained $1.7 \times 10^{-3} \mathrm{cal} /$ $\mathrm{cm}^{2} \mathrm{sec}$ for a large area of North Atlantic and $3.5 \times 10^{-3} \mathrm{cal} / \mathrm{cm}^{2} \mathrm{sec}$ for an area which just encompasses the storm.

Generation of available potential energy. The estimates of the generation of available potential energy are summarized in Table 5, with the results for both Asia and North America broken down according to month, whether the heat was added at the $1000 \mathrm{mb}$ level or distributed through the $1000-900 \mathrm{mb}$ layer, and according to contributions by time averaged and time varying parts to the total mean generation. Asian values were estimated using efficiency factors obtained from PekingTorishima cross section, while for North America estimates were obtained using the efficiency factors from both the original (Dayton-Kindley) and modified (Dayton-H-K) cross sections.

First let us consider the total mean generation $(\bar{G})$. The generation estimates for the Asian coastal waters near Shionomisaki are considerably larger than for the North American coastal waters near Cape Hatteras, particularly in the case of the estimates based on the original North American cross sections. For example, for sensible heat distribution over the $1000-900 \mathrm{mb}$ layer the average of the December and January $\bar{G}$ values for Asia is 3.85 watts $/ \mathrm{m}^{2}$ versus only 0.31 watts $/ \mathrm{m}^{2}$ for North America. As noted previously the efficiency factors near Cape Hatteras obtained from the original cross sections were unrealistically small. Consequently, the very small generation values computed using these cross sections are not surprising. The estimates of the generation based on the modified North American cross section are undoubtedly more realistic, and in the remainder of this paper these estimates will be considered as most representative of the generation near Cape Hatteras. For North America the average of the December and January means obtained using the modified cross section and for the heat addition over the $1000-900 \mathrm{mb}$ layer is 1.66 watts $/ \mathrm{m}^{2}$ as compared to the 3.85 watts $/ \mathrm{m}^{2}$ value for Asia. The larger values for Asia must be atributed to the larger efficiency factors along the Asian coast which in turn are due to the greater ocean-continent thermal contrasts in this region. It should be noted that for December the sensible heating near Cape Hatteras exceeded that near Shionomisaki, yet the December value of $\bar{G}$ is 2.95 watts $/ \mathrm{m}^{2}$ for Asia versus 1.49 watts $/ \mathrm{m}^{2}$ for North America. The mean generation for January is also larger in the Asian area, but for this month both the sensible heating and efficiency factors were greater for Asia.

The estimates based on the assumption that the sensible heat was added entirely at the $1000 \mathrm{mb}$ level are larger than those obtained when the heat was distributed over the $1000-900 \mathrm{mb}$ layer. This applies for both months and both continents. The case in which the heat is distributed over the $1000-900 \mathrm{mb}$ layer is very likely more realistic. The case of heat addition at only $1000 \mathrm{mb}$ should be considered as an upper bound of the generation estimates.

While the total mean generation estimates are for the immediate coastal waters (not more than $100 \mathrm{~km}$ from the coastline), comparable values might be expected for the waters more distant from the shore. As cold continental air moves out over the warm ocean it is rapidly modified, and not only does the air-sea temperature difference decrease but the heat is distributed over a deeper layer. Both of these changes tend to decrease the magnitude of the generation, however, as the air moves farther out over the sea the efficiency factors increase, thus compensating for the smaller air-sea temperature difference and deeper layer of heating. For example, the December mean efficiency factor in the 1000$900 \mathrm{mb}$ layer at Shionomisaki is about $33 \times 10^{-3}$, while at Torishima, the mean efficiency factor 
Table 5. Estimated values of the generation of available potential energy (watts $/ \mathrm{m}^{2}$ ). "A" and " $B$ " refer to the addition of the sensible heat at the $1000 \mathrm{mb}$ level and to the $1000-900 \mathrm{mb}$ layer, respectively.

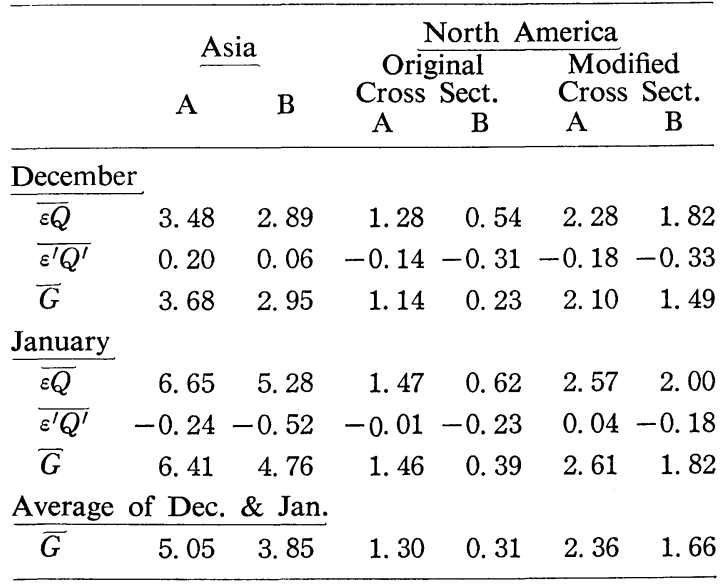

for the $1000-800 \mathrm{mb}$ layer is about $65 \times 10^{-3}$. Thus near Torishima the air-sea temperature difference could decrease to one-half the difference at Shionomaki and the heating could be distributed over a $200 \mathrm{mb}$ rather than a $100 \mathrm{mb}$ layer without any decrease in the generation.

Table 5 shows that by far the largest contribution to the total mean generation is provided by the time-averaged part, with the time varying contribution being very small and in some cases negative. Since the time-varying or perturbation part is based on deviations from the mean values of $\varepsilon$ and $Q$ rather than on whether $\varepsilon$ or $Q$ are positive or negative, there is some difficulty in interpreting the significance of the time varying part. For example, a large positive covariance $\varepsilon^{\prime} Q^{\prime}$ exists whenever the efficiency factor is larger than its mean value and the heating is larger than its mean value. This situation might be expected on a day when strong cyclogenesis occurs. On the other hand, a positive covariance also exists whenever both the efficiency factor and sensible heating are less than their mean values.

To gain some idea of the daily variations in the generation, the computer program was adjusted to print out the daily values for two months of the eight months of data. The daily values for this two month period (December 1960 - January 1961) are displayed in Figs. 9 and 10. On only a few days in the two month period was the generation negative. Since the sensible heating

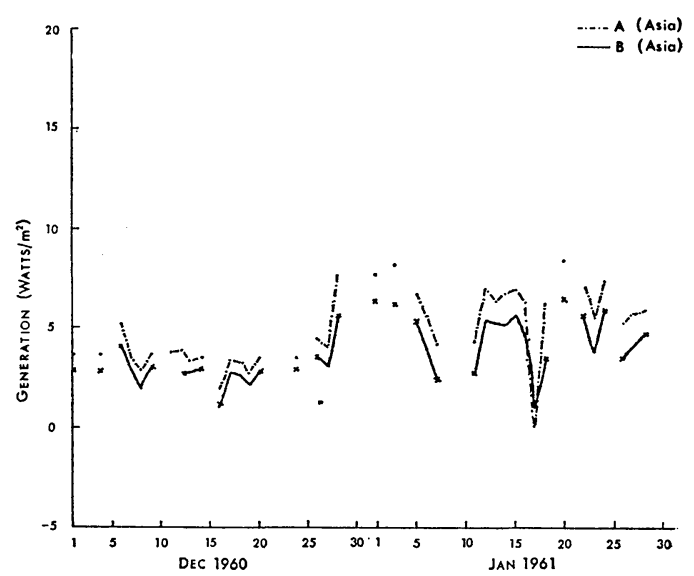

Fig. 9. Daily estimates of the generation of available potential energy by sensible heating near Shionomisaki. " $\mathrm{A}$ " is for heat addition at the $1000 \mathrm{mb}$ level. " $\mathrm{B}$ " is for heat addition distributed over the $1000-900 \mathrm{mb}$ layer.

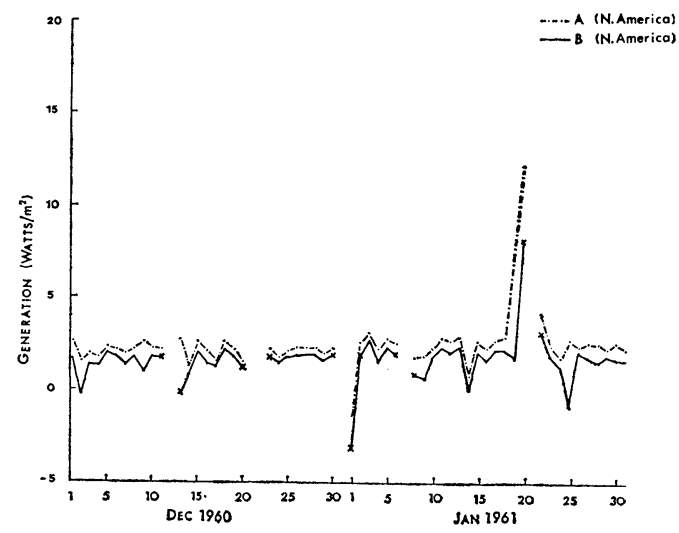

Fig. 10. Same as Fig. 9 but for the area near Cape Hatteras. These estimates were obtained using efficiency factors based on the modified North American cross sections.

was set equal to zero on days when the air was warmer than the sea, the negative values occur only when the efficiency factor becomes negative. This occurs more frequently, as expected, for cases when the heat is distributed over the 1000$900 \mathrm{mb}$ layer rather than for heat addition at $1000 \mathrm{mb}$. It also occurs more frequently at Cape Hatteras than at Shionomisaki. On some days especially large positive generation were noted, e.g., 12.0 watts $/ \mathrm{m}^{2}$ on January 20, 1961 at Cape Hatteras and 7.8 watts $/ \mathrm{m}^{2}$ on December 28, 1960 
at Shionomisaki. These values are for the sensible heat added entirely at $1000 \mathrm{mb}$. When the heat is distributed over the $1000-900 \mathrm{mb}$ layer the values are 8.0 and 5.7 watts $/ \mathrm{m}^{2}$, respectively. An inspection of surface synoptic charts revealed that the large value at Shionomisaki was accompanied by cyclogenesis. On December 28, 1960 a weak frontal wave was located just south of Kyushu (Japan). By $12 Z$ on December 29 strong cyclogenesis had occurred with the low center moving to just northeast of Tokyo. Similarly the large generation at Cape Hatteras on January 20, 1961 occurred in conjunction with strong cyclogenesis.

Finally, the estimates of the total mean generation obtained here can be compared with the results of other investigators. For purposes of comparison the average of the December and January means (3.85 watts $/ \mathrm{m}^{2}$ for Asia and 1.66 watts $/ \mathrm{m}^{2}$ for North America) will be used. These values, which represent only the contribution by sensible heating, are comparable in size to Oort's (1964) estimate of 3.1 watts $/ \mathrm{m}^{2}$ for the entire Northern Hemisphere by all diabatic processes and are somewhat less than the 5.6 watts $/ \mathrm{m}^{2}$ obtained by Dutton and Johnson (1967). When one considers that Oort's and Dutton and Johnson's values include such significant diabatic processes as latent heating and latitudinal differences in radiative heating, the climatological values obtained here seem large. However, it must be kept in mind that the area chosen for this study is one in which sensible heating is very large. Only the coastal waters off Antarctica may have comparable values. If the entire earth were used, the generation by sensible heating would likely be only a small fraction of the values obtained here.

The climatological values of the generation obtained here are comparable to the mean value of 3.1 watts $/ \mathrm{m}^{2}$ obtained by Gall and Johnson (1971) for generation by sensible heating in a single intense storm. It might be expected that the value for a single intense storm would greatly exceed the climatological value. However, it should be noted that Gall and Johnson's value represents an areal mean computed for one time, while the value obtained here represents a time mean at one point. Fig. 11 in Gall and Johnson (1971) depicts the areal distribution of the generation in the storm. It is interesting to note that at a point just east of Cape Hatteras they obtained a maximum generation of 16 watts $/ \mathrm{m}^{2}$, a value which exceeds the large daily values shown in Figs. 9 and 10.

Bullock and Johnson (1971) have investigated the generation of available potential energy by sensible heating in the boundary layer for extratropical cyclones in the Southern Ocean. For a storm area of $2000 \mathrm{~km}$ radial extent, they estimated that the average generation by sensible heating was about +0.7 watts $/ \mathrm{m}^{2}$ during the developing stage of the storm. However, the air involved in the sensible heating had moved a long distance from the Antarctic Continent and had become modified by passing over ocean water which, although warmer than the air, was not as warm as the waters east of Asia and North America.

Dissipation of kinetic energy. One method of evaluating the importance of the generation of available potential energy by a diabatic process is to compare it with the frictional dissipation of kinetic energy. Table 6 presents estimates of the mean frictional dissipation of kinetic energy based on daily wind data assumed to be representative of the wind over the oceans near Shionomisaki and Cape Hatteras. The ratio of the generation by sensible heating to the frictional dissipation is also presented. The estimates of frictional dissipation are 7.61 and 9.78 watts $/ \mathrm{m}^{2}$ near Shionomisaki for December and January, respectively, and 0.81 and 1.13 watts $/ \mathrm{m}^{2}$ near Cape Hatteras. Because the frictional dissipation depends on the cube of the surface geostrophic

Table 6. Frictional dissipation of kinetic energy (watts $/ \mathrm{m}^{2}$ ), and ratio of generation of available potential energy to frictional dissipation. Row A is based on generations obtained when the heat is added at $1000 \mathrm{mb}$ and $\mathrm{B}$ when the heat is distributed over the $1000-900 \mathrm{mb}$ layer.

\begin{tabular}{|c|c|c|c|}
\hline & & $\underline{\text { Asia }}$ & $\frac{\text { North America }}{\text { (Modified Cross Sect.) }}$ \\
\hline \multicolumn{4}{|l|}{ December } \\
\hline \multicolumn{2}{|l|}{ Dissipation } & 7. 61 & 0.81 \\
\hline \multirow{2}{*}{ Ratio (G/D) } & A) & 0.48 & 2.59 \\
\hline & B $\}$ & 0.39 & 1.84 \\
\hline \multicolumn{4}{|l|}{ January } \\
\hline \multicolumn{2}{|l|}{ Dissipation } & 9.78 & 1. 13 \\
\hline \multirow{2}{*}{ Ratio (G/D) } & A) & 0.66 & 2. 31 \\
\hline & B $\}$ & 0.49 & 1. 61 \\
\hline
\end{tabular}


wind speed, the frictional dissipation is much larger near Shionomisaki than Cape Hatteras.

The ratios of the generation to dissipation in Asia are smaller than one, while in North America they are greater than one. The larger ratios for Cape Hatteras are, of course, the result of the smaller frictional dissipation. A ratio of greater than one for the North American coastal waters implies that in this area the total mean generation by sensible heating alone is greater than the mean frictional dissipation. The excess of the generation over the dissipation can be used to increase the kinetic energy of the atmosphere locally through conversion of available potential energy to kinetic energy, or the excess may be advected away and eventually contribute to an increase in the kinetic energy in some other regions of the atmosphere.

In the case of the Asian coastal waters, it should be noted that the wind at a height of 87 meters at Shionomisaki and a regression equation were used to obtain the wind speed at a height of 10 meters above the open coastal waters. The procedure resulted in the wind speed at 10 meters being about 1.6 times greater than the wind speed at 87 meters. While the regression equation appears to be the best method of relating the wind speed at the two heights, it is possible that the wind speed over the ocean has been overestimated. If this were the case, the true frictional dissipation for the Asian coastal waters could be significantly smaller than the values obtained here.

\section{Conclusion}

The climatological results of this study indicate that the east coasts of Asia and North America are sites of very significant generation of available potential energy by sensible heating. Undoubtedly, the large generation plays an important role in making these coastal regions favored sites for frequent and intense cyclogenesis.

Of the two areas, the greatest total mean generation for the data period occurs off the coast of Asia (3.85 watts $/ \mathrm{m}^{2}$ near Shionomisaki versus 1.66 watts $/ \mathrm{m}^{2}$ near Cape Hatteras). Although the sensible heating is approximately the same in the two areas, the larger efficiency factors in Asia result in a larger generation. Since the efficiency factors depend on the variation of pressure on isentropic surfaces, the greater efficiency factors found along the Asian coast are the result of a larger thermal contrast between the continent and adjacent ocean.

The estimates of generation by sensible heating obtained in this study are of about the same size as the hemispheric values for all diabatic processes obtained by other investigators. This points to the importance of sensible heating in the cyclogenetic areas east of Asia and North America. It is also noteworthy that the climatological values of the generation near Shionomisaki and Cape Hatteras are about the same as the areal mean for a single intense storm studied by Gall and Johnson (1971).

Finally, it should be noted that near Cape Hatteras the total mean generation of available potential energy by sensible heating alone exceeds the frictional dissipation of kinetic energy, while near Shionomisaki the total generation by sensible heating is less than the dissipation of kinetic energy. It is possible that the large frictional dissipation at Shionomisaki results from overestimating the 10 meter level wind speed.

\section{Acknowledgments}

The authors wish to thank Professors J. Kutzbach and D. Johnson and Mr. D. Barber for their helpful discussions and Mr. T. Whittaker for computer programming. Our sincere gratitude also goes to the Senior Meteorologist of the Shionomisaki, Japan weather station for providing valuable information regarding the wind conditions over the ocean near Shionomisaki. This research was supported by the National Science Foundation under Grant GA-30978X.

\section{References}

Bullock, B. R. and D. R. Johnson, 1971a: The generation of available potential energy by latent heat release in a mid-latitude cyclone. Mon. Wea. Rev., 99, 1-14. tion of available potential energy by sensible heating in Southern Ocean cyclones. Quart. J. Roy. Met. Soc., 98, 495-518.

Deacon, E. L. and E. K. Webb, 1962: Interchange properties between the sea and air. The Sea, 1, ed. M. N. Hill, John Wiley \& Sons, New York, 43-87.

Dutton, J. A. and D. R. Johnson, 1967: The theory of available potential energy and a variational approach to atmospheric energetics. Advances in Geophysics, 12, Academic Press, New York, 333436.

Gall, R. L. and D. R. Johnson, 1971: The generation 
of available potential energy by sensible heating: A case study. Tellus, 23, 466-482.

Hahn, D. and L. H. Horn, 1969: The generation of available potential energy in a mid-latitude cyclone. Final Report, ESSA Grant WBG 52, Department of Meteorology, University of Wisconsin, Madison.

Johnson, D. R., 1970: The available potential energy of storms. J. Atmos. Sci., 27, 727-741.

Kung, E. C., 1963: Climatology of aerodynamic roughness parameter in the planetary boundary layer over the Northern Hemisphere. Annual Report, Contract DA-36-039-AMC-00878, Department of Meteorology, University of Wisconsin, Madison.

Laevastu, L., 1965: Synoptic scale heat exchange and its relations to weather, Proceedings of the air-sea interactions conference. Tallahassee, Fla., Technical Note 9-sail-1.

Lettau, H. H., 1962: Theoretical wind spirals in the boundary layer of a barotropic atmosphere. Beitrage zur Physik der Atmosphare, 85, 195-212.

Lorenz, E. N., 1955a: Available potential energy and the maintenance of the general circulation. Tellus, 7, 157-167.

, 1955b: Generation of available potential energy and the intensity of the general circulation. Large Scale Synoptic Processes, University of California (Los Angeles), Department of Meteoro$\log$. 1967: The nature and theory of the general circulation of the atmosphere, W.M.O., $161 \mathrm{p}$.

Malkus, J. L., 1962: Large scale interactions. The Sea,
1, ed. M.N. Hill, John Wiley \& Sons, New York, 88-294.

Manabe, S., 1958: On the estimation of energy exchange between the Japan Sea and the atmosphere during winter based upon the energy budget of both the atmosphere and sea. J. Meteor. Soc. Japan, 36, 123-133.

Ninomiya, K., 1972: Heat and water vapor budget over the East China Sea in the winter season. $J$. Meteor. Soc. Japan, 50, 1-16.

Oort, A. H., 1964: On the estimates of the atmospheric energy cycle. Mon. Wea. Rev., 92, 483-493.

Petterssen, S., D. L. Bradbury, and K. Pedersen, 1962: The Norwegian cyclone models in relation to heat and cold sources. Geophys. Publik., 24, 243-280.

Pyke, C. B., 1965: On the role of air-sea interactions in the development of cyclones. Bull. Amer. Meteor. Soc., 46, 4-15.

Reed, R. J., 1958: A graphical prediction model incorporating a form of nonadiabatic heating. $J$. of Meteor., 15, 1-8.

Roll, H. U., 1965: Physics of the Marine Atmosphere, Academic Press, N.Y.

Senior Meteorologist, 1972 (Personal Communication), Shionomisaki Weather Station, Japan.

U.S. Weather Service Command: Marine Climatic Atlas of the World, 1, The North Atlantic Ocean, 1955; 2, The North Pacific Ocean, 1957; 3, The World, 1969.

U. S. Weather Bureau, 1957-62: Northern Hemisphere Data Tabulation.

Winston, J.S., 1955: Physical aspects of rapid cyclogenesis in the Gulf of Alaska. Tellus, 7, 481-500.

\title{
アジアと北アメリカ東岸にそう顕熱による有効位置エネルギー生成
}

\author{
Kyung D. Min and Lyle H. Horn
}

米国ウイスコンシン大学

顕熱による有効位置エネルギーの生成が，アジアと北アメリカの東岸沿いの低気圧発生領域について，12月と 1 月 の 4 ケ年の期間に対して求められた。 ゾンデデータはアジアと北アメリカ東岸に直角な方向にとった毎日の断面図を 作るのに用いた。 この断面図から効率因子 (efficiency factor) の毎日の值が計算される。潮岬と Cape Hatteras 近 傍の顕熱流束にはバルク法が用いられた，この効率因子と顕熱流束とを用いて，潮岬と Cape Hatteras 近傍の平均 的な全エネルギー生成はそれぞれ $3.85 \mathrm{watt} / \mathrm{m}^{2}, 1.66 \mathrm{watt} / \mathrm{m}^{2}$ といら值で得られた. アジアでの大きな值が求めら れたのはアジア東岸での大きな効率因子のためである．これらの領域での運動エネルギーの摩擦消散も評価された。 Cape Hatteras 領域での顕熱による生成は摩擦消散をこえるが，潮岬近傍では消散の方が生成よりも幾分大きい. 